\title{
Type of Report ICSR Terminology
}

National Cancer Institute

\section{Source}

National Cancer Institute. Type of Report ICSR Terminology. NCI Thesaurus. Code C54588.

Terminology used in Individual Case Safety Reports to specify information on a report type, section G7 of FDA MedWatch Form. 